\author{
Beata Krakowiak \\ University of Łódź \\ Institut of Urban Geography and Tourism \\ Department of Geography of Tourism \\ beata.krakowiak@geo.uni.lodz.pl
}

\title{
MUSEUMS OF ŁÓDŹ AS AN ELEMENT OF TOURISM SPACE AND THE CONNECTION BETWEEN MUSEUMS AND THE CITY'S TOURISM IMAGE
}

\begin{abstract}
This article deals with the museum potential of Łódź. The first sections describe the kinds and significance of museums, their location in the city and the attractiveness of their collections, premises and organized events. The following sections describe the significance of museums in regard to attendance and the city's tourism image.
\end{abstract}

Keywords: museum, tourism attraction, tourism space, city image, cultural tourism.

\section{INTRODUCTION}

Łódź is the third most populated city in Poland, a large agglomeration and the region's capital, as well as an administrative, academic and cultural centre. Its history started in 1423 when King Władysław Jagiełło granted a charter to the former village, but its real development began in 1820, when the government of the Congress Kingdom decided to industrialise government towns (WOJALSKI 1998). Łódź was surrounded by sizeable government lands, numerous rivers and streams, easy access to building materials (timber, bricks) and had a favourable location. These factors made it possible to create textile industry settlements such as Nowe Miasto, Łódka and Nowa Dzielnica (KOTER, LISZEWSKI \& SULIBORSKI 2000), and to develop this sector of industry. The $19^{\text {th }}$ and early $20^{\text {th }} \mathrm{c}$. saw the construction of textile workshops, and then factories, tenement houses and palaces alongside the main communication route and city axis, the current Piotrkowska St. Those buildings were an expression of resourcefulness and wealth of the citizens, and Łódź evolved from a small town to a city of 300000 before the First World War. The development of the textile industry lasted until the 1990s and consolidated the image of Łódź as an industrial, gloomy and dull city in the minds of Poles. The current city authority and institutions are trying to break this stereotype and prove that Łódź is an attractive place, worth visiting.
The author of this article concentrates on one type of tourist attraction, museums, and the main goal of this work is to describe the museum potential of Łódź, presenting its location, determining its qualities and significance for the city and answering the question whether the museums are a part of the image of Łódź which is being created now.

So far, the research of the Łódź centre (mainly undergraduate theses) on museums has focused on monographs of particular establishments (WAWRZYNIAK 2008, WLAŹLAK 2011, WRZESIŃSKA 2011). The authors have also described their functions (KAŹMIERCZAK 2004, FIJAEKOWSKA 2007), significance for the city's image (NOWAKOWSKA 2012) and determined the impact on tourism (JĘDRZEJCZAK 2005, GRABOWSKAMOKRAS 2011). Sometimes, Łódź museums were mentioned as an illustration of the topic in a broader perspective, for example the Night of Museums (KRAKOWIAK \& SKRYDALEWICZ 2013) or in the context of cultural tourism (KRAKOWIAK 2013). In this article, the author suggests a more comprehensive approach, considering the current museum potential of the city.

This article is based mostly on the database (list of museums) of the National Institute for Museums and Public Collections (Narodowy Instytut Muzealnictwa $i$ Ochrony Zbiorów - NIMOZ) and information published by the museums themselves (reports, attendance) or 
websites (collections, exhibitions, events), as well as statistical data from the General Statistical Office and Łódź Statistical Office about the number in the city, voivodeship and Poland as a whole, and the museum attendance for selected years.

\section{MUSEUMS OF ŁÓDŹ: CURRENT SITUATION}

According to information from the National Institute for Museums and Public Collections, there are 14 museums in Łódź (Table 1) on its database, which means that their status has been accepted by the Minister of Culture and National Heritage. This total places Łódź behind Warsaw (60), Kraków (41) and Tricity (33, 20 in Gdańsk alone). On a regional scale, registered establishments comprise over one third of all museums in the Łódź voivodeship. Kraków has similar capital to region ratio $(36 \%)$ while in Warsaw and Tri-city this ratio is higher (42-44\%) (Table 1$)$.
Table 1. Museums in selected large Polish cities

\begin{tabular}{|c|c|c|c|}
\hline \multirow[b]{2}{*}{ City } & \multicolumn{2}{|c|}{ Number of museums } & \multirow{2}{*}{$\begin{array}{l}\% \text { of museums in } \\
\text { the voivodeship }\end{array}$} \\
\hline & $\begin{array}{l}\text { in the } \\
\text { city }\end{array}$ & $\begin{array}{c}\text { In the } \\
\text { voivodeship }\end{array}$ & \\
\hline Kraków & 41 & 113 & 36.3 \\
\hline Lódź & 14 & 37 & 37.8 \\
\hline Poznań & 9 & 72 & 12.5 \\
\hline Tri-city & 33 & 75 & 44.0 \\
\hline Warszawa & 60 & 140 & 42.8 \\
\hline Wrocław & 13 & 46 & 28.3 \\
\hline
\end{tabular}

Source: author based on information from the National Institute for Museums and Public Collections, 2015.

There are seven museums and seven branches (Table 2). Łódź City Museum has three branches while the Art Museum and the Museum of Independence Traditions have two branches each. Eódź museums are mostly organized at a local (voivodeship or powiat) level. What is important, two of those museums (Central Museum of Textiles and the Art Museum) are organized with the Ministry of Culture and National Heritage, which automatically increases their rank.

Table 2. Museums in Łódź according to registration in National Institute for Museums and Public Collections, 2015

\begin{tabular}{|c|c|c|c|c|}
\hline Name of establishment & $\begin{array}{c}\text { Founding } \\
\text { year }\end{array}$ & $\begin{array}{l}\text { Premises } \\
\text { (former function) }\end{array}$ & $\begin{array}{l}\text { Age of } \\
\text { premises }\end{array}$ & $\begin{array}{c}\text { Founder/ } \\
\text { organiser of } \\
\text { the museum }\end{array}$ \\
\hline Museum of the City of Łódź & 1975 & $\begin{array}{c}\text { Poznański Palace } \\
\text { (Poznański 'jurydyka') }\end{array}$ & $19^{\text {th }} \mathrm{c}$. & $\begin{array}{c}\text { Local } \\
\text { government }\end{array}$ \\
\hline Sports and Tourism (branch) & 1982 & Sports Hall & $\begin{array}{l}\text { second half of } \\
20^{\text {th }} \mathrm{C} \text {. }\end{array}$ & as above \\
\hline Cultures and Religious Traditions Branch & 2006 & Tenement house & $\begin{array}{l}\text { first half of } \\
19^{\text {th }} \mathrm{c} \text {. }\end{array}$ & as above \\
\hline 'Dętka' Channel Museum (branch) & 2008 & $\begin{array}{c}\text { Rain water tank (part of } \\
\text { municipal network) }\end{array}$ & $\begin{array}{l}\text { first half of } \\
20^{\text {th }} \mathrm{C} \text {. }\end{array}$ & as above \\
\hline Art Museum (ms1)* & 1930 & Poznański Palace & end of $19^{\text {th }} \mathrm{c}$. & $\begin{array}{l}\text { provincial } \\
\text { government }\end{array}$ \\
\hline Ms2 (branch) & 2008 & $\begin{array}{c}\text { Poznański factory } \\
\text { (Poznański 'jurydyka') }\end{array}$ & $\begin{array}{l}\text { second half of } \\
19^{\text {th }} \mathrm{c} \text {. } \\
\end{array}$ & as above \\
\hline Herbst Palace (branch) & 1990 & $\begin{array}{c}\text { Herbst Palace } \\
\text { (Scheibler 'jurydyka') }\end{array}$ & $\begin{array}{c}\text { second half of } \\
19^{\text {th }} \mathrm{c} \text {. } \\
\end{array}$ & as above \\
\hline $\begin{array}{l}\text { Central Museum of Textiles* } \\
\text { (+ open-air museum of wooden architecture) }\end{array}$ & 1955 & Geyer factory & $\begin{array}{l}\text { first half of } \\
19^{\text {th }} \mathrm{C} \text {. }\end{array}$ & $\begin{array}{c}\text { local } \\
\text { government }\end{array}$ \\
\hline Museum of Archaeology and Ethnography* & 1931 & School & $19^{\text {th }} \mathrm{c}$. & $\begin{array}{l}\text { provincial } \\
\text { government }\end{array}$ \\
\hline Cinematography Museum & 1984 & $\begin{array}{c}\text { Scheibler Palace } \\
(\text { Scheibler 'jurydyka') }\end{array}$ & $\begin{array}{l}\text { second half of } \\
19^{\text {th }} \mathrm{c} \text {. }\end{array}$ & $\begin{array}{c}\text { local } \\
\text { government }\end{array}$ \\
\hline The Museum of Independence Traditions & 1959 & Tsar's prison & $19^{\text {th }} \mathrm{c}$. & as above \\
\hline Martyrology Museum Radogoszcz (branch) & 1976 & Abbe factory & end of $19^{\text {th }} \mathrm{c}$. & as above \\
\hline $\begin{array}{l}\text { Radegast station Museum (branch) } \\
(+ \text { 'Gypsy Forge') }\end{array}$ & 2004 & Marysin railway station & $\begin{array}{l}\text { first half of } \\
20^{\text {th }} \mathrm{C} \text {. }\end{array}$ & as above \\
\hline Art Book Museum & 1993 & Grohman Palace & end of $19^{\text {th }} c$. & $\begin{array}{c}\text { private } \\
\text { foundation }\end{array}$ \\
\hline
\end{tabular}

* Registered museums.

Source: author. 
Three have the significant position of a registered museum $^{1}$ - Central Museum of Textiles, Art Museum and Museum of Archaeology and Ethnography. The group contains only one private institution, the Book Art Museum created by a foundation.

The history of Łódź museums begins in the interwar period with the founding of the City Museum, which later gave rise to the Museum of History and Art and the Ethnographic Museum. Most of the institutions were founded in the second part of $20^{\text {th }} \mathrm{c}$. and have established their position since then (Table 2). Several institutions were founded in the early 2000s; these are branches of existing museums (Radegast Station, ms2, 'Dętka' Channel Museum).

Museums that are added to NIMOZ list are important museums, usually telling the story of the city's history and heritage. They are mentioned in all city guides and information leaflets, and are promoted on websites and internet portals. Apart from them ${ }^{2}$, there are private museums founded by institutions, societies and foundations. They complete the city's offer in terms of cultural institutions, but due to their diverse rules are usually of lesser significance (Museum of the Factory and SE-MA-FOR Museum of Animation are exceptions) they will not be analysed further in this paper.

If we consider the museums of the biggest Polish cities, we will see that they attract tourists and the highest level (national) museums most of all. Unfortunately, the only city (Table 1) without one is Łódź (while Szczecin, Kielce or Przemyśl do). Łódź lacks a museum of national significance that would be popularly associated with it and at the same time be the main attraction, like Wawel Castle in Kraków, Wilanów Palace in Warsaw or Racławice Panorama in Wrocław. Some large cities gain in significance thanks to new museums because of the building they are in or the way the collection is exhibited (e.g. Warsaw Uprising Museum, Museum of the History of Polish Jews, new branches of the History Museum in Kraków 'Rynek Underground', Oskar Schindler's Factory). Unfortunately, there are no museums of this rank in Łódź and no plans to found them. The Art Museum (ms2) which could be a showcase of the city is not popular enough among regular tourists and lacks promotion outside the city.

\section{LOCATION OF MUSEUMS IN THE CITY}

The location of museums influences their availability to potential visitors but usually they are not distributed evenly, being clustered in certain parts of the city.

In medieval cities, the highest concentration is within one $\mathrm{km}$ of an old market square. This area usually has the highest density of historical buildings that can be used as museums, which gives both protection to cultural heritage and displays the buildings' interiors as an appropriate background and decoration for exhibitions (KRAKOWIAK 2008). A similar pattern can be seen in Łódź (Fig. 1). Museums are located mostly in the Śródmieście district (and surrounding areas) which has the function of a city centre, with Piotrkowska St as its axis.

This is the historic and administrative heart of the city, and museums are placed among other attractions: former tenement houses, villas, factories and parks. This way, the museums are a part of the historical space of the city and are elements of its cultural space.

In general, museums in Łódź are located in its vicinity, especially east-west. Located in the most northern positions compared to the rest are two branches of the Museum of Independence Traditions: the Martyrology Museum Radogoszcz and Radegast Station Museum

Figure 2 shows the area of museum concentration and its location in the city, forming a polygon with an elongated north-south axis. Unlike medieval towns, Łódź (a city without a square, but with a main street), the largest number of museums are within $1-3 \mathrm{kms}$ of the notional city centre, but not in its immediate vicinity. This area contains 12 out of 14 institutions. The densest concentration is near plac Wolności, the former New Town market square, and its neighbouring trade and entertainment complex (former Poznański factory).

There are six museums from the NIMOZ list in this area. This could mean that there is a 'museum island' (just as in Amsterdam, Berlin or Vienna), but since there is no connection between them, this is unfortunately not the case.

The described museums 'co-create' the cultural city space, but they do not cooperate, or only in a very limited way, for example during the Night of Museums. However, they are certainly a part of the tourism city space of Łódź (LISZEWSKI 1999) and are visitor destinations.

\section{MUSEUMS OF ŁÓDŹ AS TOURISM ATTRACTIONS}

According to its definition, a tourism attraction is an element of natural or other environment, which becomes the subject of a tourist's interest and determines the tourism attractiveness of a given place (KOWALCZYK 2001). Museums, of course are 'anthropogenic' attractions, and their significance is determined by the collection, premises or organized events. 


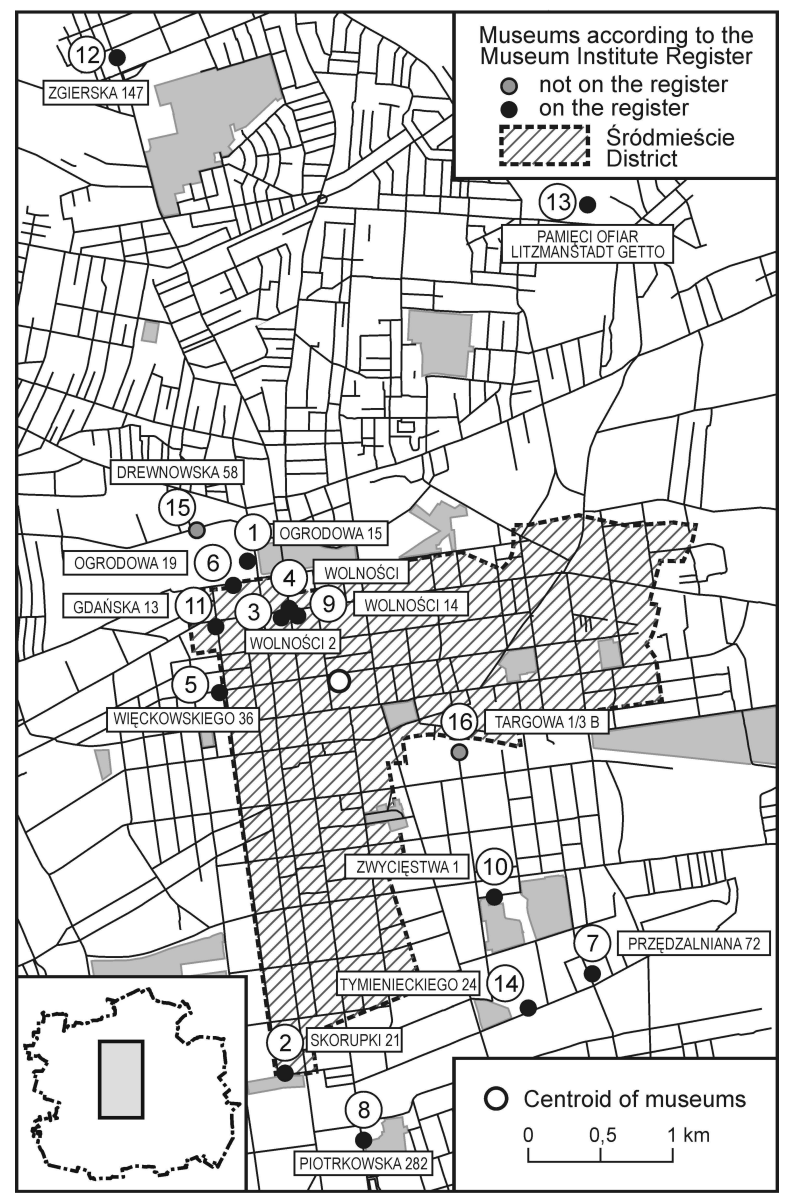

Fig. 1. Location of museums in Łódź

1 - Łódź City Museum

2 - Sport and Tourism Museum

3 - The Cultures and Religious Traditions Branch

4 - 'Dętka' Channel Museum

5 - Art Museum (ms1)

$6-\mathrm{ms} 2$

7 - Herbst Palace Museum

8 - Central Museum of Textiles

9 - Museum of Archaeology and Ethnography

10 - Cinematography Museum

11 - The Museum of Independence Traditions

12 - Martyrology Museum Radogoszcz

13 - Radegast Station Museum

14 - Art Book Museum.

Museums not on the NIMOZ list:

15 - Factory Museum,

16 - Se-ma-for Museum

Source: author

Fig. 2. Concentration of museums in Łódź

Source: author

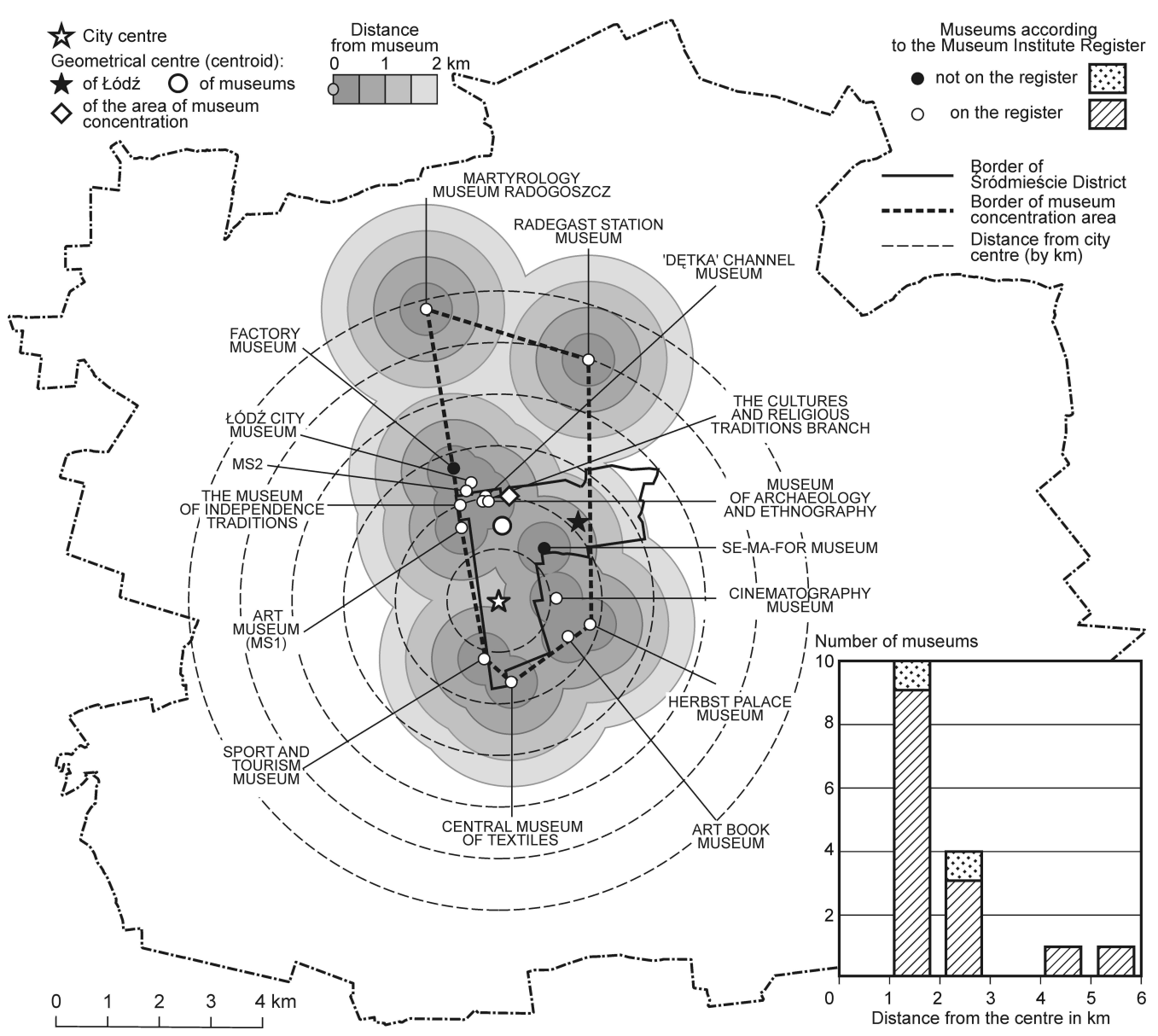




\subsection{COLLECTIONS AND EVENTS}

The collection is a decisive factor of a museum's character; it determines its profile and influences the kind of people who visit. The museums of Łódź (Table 3) are dominated by historical collections and so-called Łodziana (Museum of the City of Łódź, Cultures and Religious Traditions Branch).

Table 3. Collections in Łódź museums: 2015

\begin{tabular}{|c|c|}
\hline $\mathrm{am}$ & Subject of exhibition / collection \\
\hline $\begin{array}{l}\text { Lódź City } \\
\text { Museum }\end{array}$ & $\begin{array}{l}\text { 'Former Łódź. History - culture - everyday } \\
\text { life'; 'Gallery of Polish Masters' }\end{array}$ \\
\hline $\begin{array}{l}\text { Sports and } \\
\text { Tourism Museum }\end{array}$ & $\begin{array}{l}\text { ‘History of Sport in Łódź'; 'Greatest } \\
\text { accomplishments of Łódź athletes'; } \\
\text { ‘Citizens of Łódź in the Olympic games' }\end{array}$ \\
\hline $\begin{array}{l}\text { The Cultures and } \\
\text { Religious } \\
\text { Traditions Branch }\end{array}$ & $\begin{array}{l}\text { The multi-religious spiritual and cultural } \\
\text { heritage of Łódź }\end{array}$ \\
\hline $\begin{array}{l}\text { ‘Dętka' Channel } \\
\text { Museum }\end{array}$ & $\begin{array}{l}\text { Presentation of the municipal sewer } \\
\text { designed by the British engineer W. Lindley }\end{array}$ \\
\hline $\begin{array}{l}\text { Art Museum } \\
(\mathrm{ms} 1)^{*}\end{array}$ & Contemporary art; temporary exhibitions \\
\hline ms2 & Avant-garde art; $19^{\text {th }}$ \\
\hline $\begin{array}{l}\text { Herbst Palace } \\
\text { Museum }\end{array}$ & $\begin{array}{l}\text { ‘Herbst Palace - Old art in new dimension'; } \\
\text { 'Gallery of Old Art', 'Herbst Family: } \\
\text { unfinished stories' }\end{array}$ \\
\hline $\begin{array}{l}\text { Central Museum } \\
\text { of Textiles* } \\
(+ \text { open-air } \\
\text { museum of } \\
\text { wooden } \\
\text { architecture) }\end{array}$ & $\begin{array}{l}\text { 'Fashion in the } 20^{\text {th }} \text { c.'; 'Reconstruction of } \\
\text { a loom mill from the } 19 / 20^{\text {th }} \text { c. 'Machines } \\
\text { in motion'; 'Tools and weaving machines } \\
\text { in the collection of the Central Museum of } \\
\text { Textiles'; 'Ludwik Meyer factory } 1828-2002^{\prime} \text {; } \\
\text { 'Kotłownia - interactive museum' } \\
\text { Open air museum: 'Pani Goldberg's } \\
\text { kitchen', 'Reconstruction of worker's flats } \\
\text { from the } 1920 \text { s and } 30 s^{\prime}, \text { 'Reconstruction } \\
\text { of an early } 19^{\text {th }} \text { c. workshop', 'Old Łódź } \\
\text { crafts - tailor's workshop'. }\end{array}$ \\
\hline $\begin{array}{l}\text { Museum of } \\
\text { Archaeology and } \\
\text { Ethnography* }\end{array}$ & $\begin{array}{l}\text { 'Archaeology exhibition'; 'Grey like the } \\
\text { soil, colourful as memory (ethnography } \\
\text { exhibition); 'Coins on Polish territory' }\end{array}$ \\
\hline tography & $\begin{array}{l}\text { 'From negative to copy'; 'Flying machine'; } \\
\text { 'Secrets of the film set'; 'History of the } \\
\text { Scheibler Film Palace'; 'Cinematograph's } \\
\text { equal: the magic of photoplasticon seances'; } \\
\text { 'The miracle of living photography'; 'Palace } \\
\text { of fairytales' }\end{array}$ \\
\hline $\begin{array}{l}\text { The } \\
\text { Ind } \\
\text { Tra }\end{array}$ & $\begin{array}{l}\text { 'Długa (Gdańska) St prison in Łódź 1885- } \\
\text { 1953'; ' Roads to Independence 1791-1921' }\end{array}$ \\
\hline $\begin{array}{l}\text { Martyrology } \\
\text { Museum Radogo- } \\
\text { szcz (branch) }\end{array}$ & $\begin{array}{l}\text { 'The fates of the citizens of Łódź during } \\
\text { the Second World War'; 'The history of } \\
\text { the police jail in Radogoszcz 1939-45' }\end{array}$ \\
\hline $\begin{array}{l}\text { Radegast Station } \\
\text { Museum }\end{array}$ & $\begin{array}{l}\text { 'The history of Litzmannstadt Ghetto 1940- } \\
44^{\prime} ; \text { 'Schwartz family trunk' }\end{array}$ \\
\hline $\begin{array}{l}\text { Art Book } \\
\text { Museum }\end{array}$ & $\begin{array}{l}\text { 'CdA books'; ' the Polish Art Book from } \\
\text { the turn of } 20^{\text {th }} \text { c.'; 'Grohman graphics } \\
\text { collection'; 'Machines and appliances } \\
\text { of the Gutenberg era' }\end{array}$ \\
\hline
\end{tabular}

* Museums on the National Museum Register.

Source: author's compilation based on information provided by museums.
The emphasis is placed on that part of history connected with the development of the city in the $19^{\text {th }}$ c., the communities inhabiting Łódź at that time (Polish, Jewish, German and Russian), and significant citizens (Reymont, Tuwim, Rubinstein and Kosiński). Historical collections are also presented in the Museum of Independence Traditions and its two branches connected with the Second World War. One of them documents the founding and functioning of the police camp (Martyrology Museum Radogoszcz), the other the period of the existence and then liquidation of the Łódź ghetto and deportation of the Jewish population to death camps (Radegast Station Museum). Those establishments are martyrological in character. Exhibitions in the Central Museum of Textiles (textile machines) or Herbst Palace (factory owner interiors) are connected with the history of the city; they give knowledge on the city's and its citizens' pasts.

Another type of museum is that with art collections, such as the Art Museum and its two branches. This is mostly associated with its international collection of modern art, and also with its founders - Strzemiński and Kobro (a.r group). At the moment, it is the only Polish museum with such an extensive collection of international art from the $20^{\text {th }}$ and $21^{\mathrm{st}} \mathrm{c}$. (www.msl. org.pl), and its location is one of the most recent - ms2 museum. The Gallery of Old Art in the Herbst Palace Museum presents works by European and Polish masters (including Rodakowski, Michałowski and Wyspiański). The exhibition encompasses representational interiors decorated with splendour, and the private quarters of the owners, while its appropriate organisation allows the visitors to feel the mood of the time (www.msl.org.pl). The interior of the City Museum in a former industrialist palace which houses the Polish Masters Gallery has a similar character.

Not all museums in Łódź can be connected by thematic group; some contain exhibitions on a variety of subjects. Artistic and technical collections can only be found in the Museum of Cinematography in Poland, which has a collection of Polish cinema artefacts connected to significant productions and people. The inconspicuous Art Book Museum has a similar character, with exhibitions of printing machines and modern art books; at the same time it is an institution that has received many awards in the field of unique book editions. Technical museums include the only Textiles Museum in Poland, also containing artistic fabrics, and next door an open-air museum has an exhibition of buildings (weaver huts, church) connected with the everyday life and work of the former inhabitants of Łódź and its industrial region (Polityka rozwoju kultury...).

There are several museums of a different character and with exceptional collections such as the 'Dętka' Channel Museum, Museum of Archaeology and Ethno- 
Table 4. Selected regular events organized by the museums of Łódź: 2015

\begin{tabular}{|c|c|c|}
\hline $\begin{array}{l}\text { Name of the } \\
\text { museum }\end{array}$ & Subject & Characteristics \\
\hline \multirow[t]{2}{*}{$\begin{array}{l}\text { Central Museum of } \\
\text { Textiles (organiser) }\end{array}$} & $\begin{array}{l}\text { International Triennial of } \\
\text { Tapestry }\end{array}$ & $\begin{array}{l}\text { Taken place since 1972: promotes contemporary tapestry art, in the form } \\
\text { of a contest accompanied by additional events. So far there have been } 14\end{array}$ \\
\hline & Geyer Music Factory & $\begin{array}{l}\text { Organised since 2008: in the form of encounters with various music } \\
\text { genres and musicians from various parts of the world. Takes places on a } \\
\text { selected day of the week during the summer months in the museum } \\
\text { courtyard. }\end{array}$ \\
\hline $\begin{array}{l}\text { Animation } \\
\text { Museum Se-Ma-For } \\
\text { Muzeum Animacji } \\
\text { (organiser) }\end{array}$ & $\begin{array}{l}\text { Se-Ma-For Film Festival (interna- } \\
\text { tional festival of puppet anima- } \\
\text { tion and other three-dimensional } \\
\text { stop-motion animation } \\
\text { techniques ) }\end{array}$ & $\begin{array}{l}\text { Organised since 2010: aimed at creating a forum for film co-production } \\
\text { issues. Festival is in a form of a contest accompanied by film screenings. }\end{array}$ \\
\hline $\begin{array}{l}\text { The Museum of } \\
\text { Independence } \\
\text { Traditions } \\
\text { Radegast Station } \\
\text { (co-organiser) } \\
\end{array}$ & $\begin{array}{l}\text { Anniversary of the Liquidation } \\
\text { of Litzmannstadt Ghetto }\end{array}$ & $\begin{array}{l}\text { Organised since 2004: the celebration lasts for several days and takes } \\
\text { place in various parts of the city connected with the Jewish community } \\
\text { in the past. }\end{array}$ \\
\hline \multirow[t]{2}{*}{$\begin{array}{l}\text { Cinematography } \\
\text { Museum } \\
\text { (organiser) }\end{array}$} & $\begin{array}{l}\text { Media Festival Humanity in } \\
\text { Danger }\end{array}$ & $\begin{array}{l}\text { Taken place since 1990: it is a review of documentaries dealing with the } \\
\text { threats faced by people and the environment. It presents films, television } \\
\text { programs, videos and radio features. }\end{array}$ \\
\hline & $\begin{array}{l}\text { Film Music Festival (temporarily } \\
\text { suspended) }\end{array}$ & $\begin{array}{l}\text { Organised since 1997: each is devoted to a different film music composer } \\
\text { from Poland. Events include film screenings and meetings with the } \\
\text { artists. }\end{array}$ \\
\hline $\begin{array}{l}\text { Łódź City Museum } \\
\text { Factory Museum } \\
\text { (organiser) }\end{array}$ & Poznański's birthday & $\begin{array}{l}\text { Recent: it entertains and aims at popularisation of the museum located } \\
\text { in Poznański's former factory, introduces the man himself and the } \\
\text { history of industrial Łódź }\end{array}$ \\
\hline
\end{tabular}

Source: author.

graphy, and the Sports and Tourism Museum. Despite the specialized character of their collections (history, art, technology), museums in Łódź are exceptional for their region, and some even nationally (Cinematography Museum, Central Museum of Textiles, Art Museum).

Some museums have significance not only thanks to the collections, but also regular organized events on a regional, national or international scale. The most popular are the International Triennial of Tapestry the oldest and largest world exhibition promoting modern art tapestry (connected to the city's history) organized by the Central Museum of Textiles; or the Geyer Music Factory - a music event that takes place in the summer in the museum's courtyard.

The Museum of Cinematography is associated with the Media Festival 'Humanity in Danger', and the currently suspended Film Music Festival, while the Museum of Independence Traditions and its branch at Radegast Station organizes the celebrations of the Anniversary of the Liquidation of the Litzmannstadt Ghetto. (The detailed description of events on Table 4 mentions museums from outside the NIMOZ list, because of their part in organising or financing significant cultural events.) Apart from those events, the museums of Łódź also organize more local ones such as Sunday at Geyers' (Central Museum of Textiles), Sunday in the Palace (City Museum), or they take part in organizing Łódźs Birthday, thus complementing their cultural offer and draw on the city's past.

\subsection{MUSEUM PREMISES}

The museums of Łódź attract visitors not only with their collections and events, but also with the buildings themselves, their appearance, characteristic features, original purpose or the owner's name. From the historical point of view, it is important that most of the premises come from the industrial period of the city, are historically consistent and represent the category of typical Łódź buildings from the late 19th and early $20^{\text {th }}$ c. (Table 2). Many of those buildings are on tourism trails, either trails of industrial architecture, villas and palaces, or cultural trails (Jewish or German trails), and are an important tourism attraction. Five premises are former industrialists' residences, usually built after achieving business success and a certain financial status. They were closely connected with the factories, formed a structural unity with them and were distinguished by opulent form and architectural 
detail, including allegories of industry, trade and craft (LAURENTOWICZ-GRANAS \& MANDŻETT-KUBIAK 1997).

Famous Łódź architects such as Hilary Majewski and Franciszek Chełmiński took part in designing those buildings, finding inspiration from earlier epochs. The interior design combined a public function (living room, dining room, and ballroom) with a domestic function (private quarters). Luxurious and comfortable interiors can be seen in the City Museum (Poznański Palace and Cinematography Museum (Scheiler Palace), and Herbst Palace.

Technological buildings (five examples) are another category, such as the first mechanized factory in Łódź belonging to Geyer (Central Museum of Textiles) and the factory of one of the most prominent cotton manufacturers - Poznański (ms2). Both are examples of multi-storey factories that used to contain hundreds of mechanical looms and created the city's industrial landscape. (JASKULSKI 1995). An unusual technologyrelated location is the former Marysin railway station and a section of the first waterworks in the city a former sewer adapted as an underground museum. Three utility buildings (school, prison and sports hall) and one residence (tenement house) are also in this category.

Most of these locations were listed as historical buildings and are under preservation maintenance due to their period, architecture, interiors, and the heritage of members of cultures that inhabited Łódź in the $19^{\text {th }}$ and early $20^{\text {th }}$ c. In addition, in February 2015, several were recognized as historical monuments (Geyer, Scheibler and Poznański factory-residential complexes)

Another category worth mentioning is memorials. Radegast Station Museum is one; it was opened during the $60^{\text {th }}$ anniversary of Łódź ghetto liquidation and is connected with a historical Jewish cemetery by a memorial trail creating a consistent martyrological complex. The Martyrology Museum Radogoszcz is similar; it was a transit prison for men during the Second World War, and is now a mausoleum.

The overview of Łódź museums sets out their distinctive tourism value. They can be tourism attractions, especially thanks to current revitalisation and the chance to get outside funds (e.g. the latest renovation in the Art Museum and its branches and in the Central Museum of Textiles).

\section{5. ŁÓDŹ MUSEUMS AND THE CITY'S IMAGE}

One way to get ahead in inter-city competition is to create a positive image. Image is the sum of ideas, attitudes and feelings that a person or a group of people has with regard to a given place, in this case, a city. It is a subjective judgement, a concept which is often the main factor in deciding whether to visit that city or not (www.regiobooks.pl). A specific image is the result of deliberate promotional actions of a territorial or city marketing character, conducted by local government, municipal institutions and the media.

The recent years there have been a series of investments that are to revitalize Łódź, improve its functioning and image. The largest undertaking at the moment is the building of a new Łódź Fabryczna railway station and adjustments to the line, which will allow Łódź to have a high-speed connection to Warsaw, and in the future with Wrocław and Poznan. This project is connected with the development of so-called 'New Centre of Łódź' (Nowe Centrum Łodzi - NCŁ). This area will consist of revitalised post-industrial, railway locations, former city residential quarters and creatively adapt the urban fabric from the $19^{\text {th }}$ and $20^{\text {th }} \mathrm{c}$. It will have new functions, including a cultural function. The buildings of the old power plant (EC-1) will house the Film Art and Interactive Science and Technology Centres. New Centre Market and Special Art Zone will be built in the power plant surroundings (www. ncl.uml.lodz.pl). This project is a part of the series aimed at revitalising the former industrial city. In the past, similar projects resulted in the development of Manufaktura - a commercial-entertainment centre, residential complex 'Lofty $u$ Scheiblera' and 'Off Piotrkowska', a project for the creative industries.

Independently of creating new service areas, the 'mia100 Kamienic' project, founded in 2011 deals with renovation of neglected residential buildings located in the city centre. It should be mentioned that the city has been using the motto 'Eódź creates' to promote the city and provide conditions for realising creative ideas that contribute to the city's image.

New institutions aimed at developing creative ideas were founded, such as Łódź Art Center (responsible for organizing Fotofestiwal, Łódź Design Festival, as well as Art Inkubator project for creative entrepreneurs) of the Urban Forms Foundation (which creates large format murals on the walls of tenement houses Urban Forms Gallery). There are also many festivals and cultural events, and their number has been increasing since Łódź began its attempts to achieve the European Capital of Culture title in 2016.

This overview of the city's activities is selective and aimed at emphasizing the main themes from those projects, the city development strategy and its promotion, and also correspond with the title of this article. These include:

1. History - connected with the city's past, weaving traditions, multiculturalism, and the idea of identity (Łódź of four cultures). 
2. Art - sources of contemporary art, many dimensions of modern art, avant-garde, fashion, as well as street art (Łódź - the city of art).

3. Film - the filmmaking tradition in the city (fulllength and short forms), film locations, characters, actors (film Łódź, Hollyłodź).

These motifs are the base of the city's image, affecting the way it is perceived and evoking particular associations. They create the image of Łódź as a postindustrial city, a city of film and art. The simplified version of the connection between those themes and the elements appearing and working in city space are shown in Table 5.

The museums were added to this list, to show that almost all of them fit the image motifs of the city (it contains two museums that are not on the NIMOZ list, but fit the concept) and enhance the development of various forms of tourism in the city. The museums mentioned correspond both with the city's history (which is shown in their description) and culture represented by motifs of film and art. Using these institutions to create a new city image seems justified because they are tourism attractions for Łódź, a city visited by an estimated 1.2 million tourists every year. The significance of the museum is confirmed by the tourist service TripAdvisor, according to which Radegast Station Museum and Central Textile Museum were among the 10 highest-rated attractions, and Cinematography Museum, Art Museum, Herbst Palace Museum, Poznański Museum, Se-ma-for Animation Museum and Factory Museum were among the next ten (Trip Advisor.com).

Despite high positions in the ranking of tourism attractions, the museums of Łódź (except for the Central Museum of Textiles and Radegast Station Museum) are visited by only 20-30 000 visitors a year (Fig. 3) which is lower than the average number for a Polish museum (according to statistical yearbooks, one museum in Łódź had 257000 visitors on average per year, while the average for a museum in Poland was 347000 visitors). Therefore, they are not able to compete with popular museums in other cities, e.g.

Table 5. Leading motifs of the image of Łódź and connected elements of city space

\begin{tabular}{|c|c|c|c|}
\hline \multirow{2}{*}{ Category } & \multicolumn{3}{|c|}{ Motifs } \\
\hline & history & film & art \\
\hline $\begin{array}{l}\text { Museums in the } \\
\text { city }\end{array}$ & $\begin{array}{l}\text { Łódź City Museum, Central Museum } \\
\text { of Textiles, Herbst Palace Museum, } \\
\text { Martyrology Museum Radogoszcz, } \\
\text { Radegast Station Museum, Factory } \\
\text { Museum }\end{array}$ & $\begin{array}{l}\text { Cinematography Museum } \\
\text { Animation Museum } \\
\text { Se-ma-for }\end{array}$ & $\begin{array}{l}\text { Art Museum, ms2, Herbst palace } \\
\text { Museum, Łódź City Museum, Art } \\
\text { Book Museum }\end{array}$ \\
\hline $\begin{array}{l}\text { Connected } \\
\text { institutions and } \\
\text { organisations } \\
\text { (examples) }\end{array}$ & $\begin{array}{l}\text { Piotrkowska St Foundation, Łódź of } \\
\text { Four Cultures, Edelman Dialogue } \\
\text { Centre }\end{array}$ & $\begin{array}{l}\text { Film School in Łódź, Se-ma-for } \\
\text { Film Production, Łódź Film Studio } \\
\text { (complex on Łąkowa St) }\end{array}$ & $\begin{array}{l}\text { Fine Arts Academy, Music Academy, } \\
\text { Łódź Concert Hall, Grand Theatre } \\
\text { Łódź, Łódź Art Center, Art Factory, } \\
\text { Urban Forms Foundation (murals) }\end{array}$ \\
\hline $\begin{array}{l}\text { Attractions } \\
\text { in the city } \\
\text { (examples) }\end{array}$ & $\begin{array}{l}\text { Piotrkowska St, former jurydykas of } \\
\text { Poznański and Scheibler, plac Wolności } \\
\text { Historical buildings: factories, } \\
\text { tenement houses, temples, Old } \\
\text { Cemetery, Jewish Cemetery, thematic } \\
\text { trails of multicultural Łódź (Jewish, } \\
\text { German, Russian, industrial Łódź) } \\
\end{array}$ & $\begin{array}{l}\text { Łódź Walk of Fame, Film Łódź } \\
\text { trail, 'Eódź Bajkowa' trail, 'Stare Kino' } \\
\text { Hotel }\end{array}$ & $\begin{array}{l}\text { OFF Piotrkowska, Art Inkubator, } \\
\text { Urban Forms Gallery, Gallery of } \\
\text { Great Citizens of Łódź, thematic } \\
\text { trails (murals, industrial architecture, } \\
\text { villas and palaces) }\end{array}$ \\
\hline $\begin{array}{l}\text { Events in } \\
\text { the city } \\
\text { (examples) }\end{array}$ & $\begin{array}{l}\text { Four Cultures Festival, Anniversary of } \\
\text { the Liquidation of Litzmannstadt } \\
\text { Ghetto, Light Movie Festival, } \\
\text { Fashion Week Poland }\end{array}$ & $\begin{array}{l}\text { Se-Ma-For Film Festiwal, } \\
\text { International Festival of Film and } \\
\text { Television Schools, European } \\
\text { Cinema Forum 'Cinergia', Festival } \\
\text { of Civilisation and Audiovisual Art } \\
\text { Mediatravel, Transatlantyk festival }\end{array}$ & $\begin{array}{l}\text { Art Museum, ms2, Herbst palace } \\
\text { Museum, Łódź City Museum, Art } \\
\text { Book Museum }\end{array}$ \\
\hline \multirow[t]{2}{*}{$\begin{array}{l}\text { Symbols } \\
\text { of the city }\end{array}$} & Manufaktura, Priest's Mill & $\begin{array}{l}\text { Łódzka 'Filmów ka', Studio Filmowe } \\
\text { Se-Ma-For }\end{array}$ & New Łódź Centre, EC-1 \\
\hline & \multicolumn{3}{|c|}{ Piotrkowska St } \\
\hline Tourism form & $\begin{array}{l}\text { Cognitive tourism, urban cultural } \\
\text { tourism, industrial tourism }\end{array}$ & $\begin{array}{l}\text { Cognitive tourism, cultural, film, } \\
\text { entertainment tourism }\end{array}$ & $\begin{array}{l}\text { Cognitive, cultural entertainment } \\
\text { tourism }\end{array}$ \\
\hline
\end{tabular}

Source: author's compilation. 
Racławice Panorama in Wrocław (around 260000 visitors), Oskar Schindler's Factory in Kraków (around 270000 visitors), or the Warsaw Uprising Museum (around 490000 visitors). Apart from this, we must remember, that a proportion of visitors, are citizens of the city or the surrounding area.

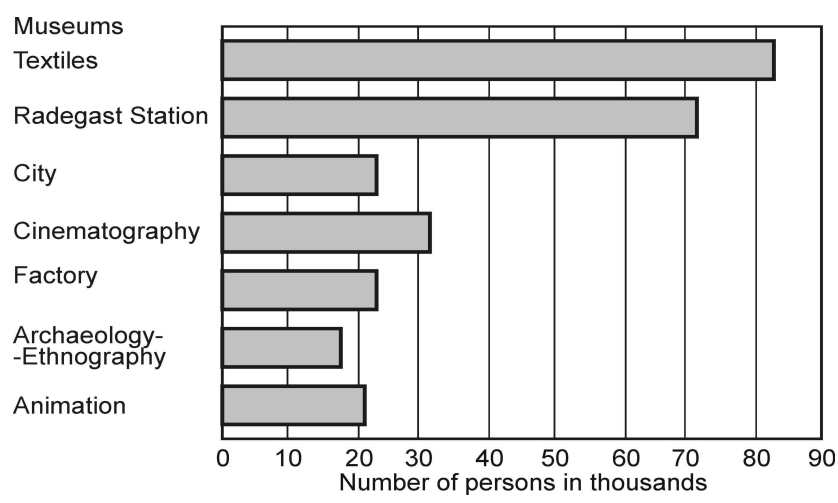

Figure 3. Attendance at selected museums in Łódź: 2013

Source: author based on museum statistics

Table 6. Attendance at museums in Poland, Łódź voivodeship and Łódź: 2008-13

\begin{tabular}{|l|r|r|r|r|}
\hline \multirow{2}{*}{} & \multicolumn{4}{|c|}{ Attendance in the year } \\
\cline { 2 - 5 } & 2008 & 2010 & 2012 & \multicolumn{3}{|c|}{2013} \\
\hline $\begin{array}{l}\text { Visitors in museums } \\
\text { (in 000s) }\end{array}$ & $20,726.5$ & $22,215.7$ & $26,709.5$ & $29,043.8$ \\
\hline - in Poland & 569.1 & 709.0 & 724.0 & 906.4 \\
\hline $\begin{array}{l}\text { - in Łódź } \\
\text { voivodeship }\end{array}$ & 218.0 & 225.0 & 389.0 & 488.1 \\
\hline - in Łódź & \multicolumn{4}{|c|}{} \\
\hline $\begin{array}{l}\text { \% of visitors in the } \\
\text { museums }\end{array}$ & 38.3 & 31.7 & 53.7 & 53.8 \\
\hline $\begin{array}{l}\text { - in the Łódź } \\
\text { voivodeship }\end{array}$ & 1.0 & 1.0 & 1.4 & 1.7 \\
\hline - in Poland & \multicolumn{4}{|c}{} \\
\hline
\end{tabular}

Source: author based on statistical yearbooks of Łódź (2010, 2014) and Łódź voivodeship (2009, 2011, 2013, 2014).

In 2013 the museums in Łódź were visited by around 490000 people, which means that they have a significant role in the region, $53.8 \%$ of that for the voivodeship, but it is just $1.7 \%$ of that for the whole of Poland (Table 6). Presented information confirms that museum integration and joint promotion of the institutions along with a more decisive promotional campaign within marketing actions of the local authorities is necessary for the museums to gain more popularity and attract visitors from outside the city.

\section{CONCLUSION}

Ideas in this article inspire the following conclusions:

1. Museums in Łódź create a geographically concise space, with a north - south orientation, connected with the city's main axis - Piotrkowska St. The museums are located mostly in the Śródmieście district and are a part of tourism space.

2. The museums use the potential of the $19^{\text {th }}$ and $20^{\text {th }} \mathrm{c}$. in terms of buildings (former residences, technological buildings), collections (history, art, technology), and events (International Trienniale of Tapestry, Anniversary of Liquidation of the Litzmannstadt Ghetto). Those elements contribute to the tourism attractiveness of the institutions.

3. The museums, despite their tourism attractiveness, have a low attendance, 20-30 000 visitors a year on average, so they are locally, but not nationally significant. A chance to promote knowledge about the museums in Łódź (and their attendance) would be an appropriate cultural policy on the part of local government, as well as better promotion as part of marketing activities.

4. Each museum separately has a limited influence on the way Łódź is perceived, so it is advisable to add them as a motif creating the city image (history, film, art). This strategy would be beneficial for all parties - the city would consolidate its image, while the museums would gain significance in the context of new investments in the city.

\section{FOOTNOTES}

${ }^{1}$ Registered museum - museum on the National Register of Museums. Entry depends on the significance of the museum's collection, qualified staff, premises and permanent source of income, which allows it to perform its statutory duties (Museums Act).

2 Museums in Łódź which are not on NIMOZ list: Se-ma-for Museum of Animation, Łódź Archdiocese Museum, Factory Museum, Pharmacy Museum, Museum of Transport, Museum of Children's Books, Museum of Education, Museum of Paper and Print, Łódź University Museum, Museum of Geology of the University of Łódź, Museum of Nature of the University of Łódź, Museum of the Medical University of Łódź, 'Experymentarium' Science Centre.

Translated by Katarzyna Zielińska

\section{BIBLIOGRAPHY}

FIJAŁKOWSKA J., 2007, Muzeum Sportu i Turystyki w Łodzi jako obiekt turystyczno-krajoznawczy, master thesis written in the Institute of Urban Geography and Tourism Studies, University of Łódź, Łódź. 
JASKULSKI M., 1995, Stare fabryki Łodzi, Towarzystwo Opieki nad Zabytkami, Oddział w Łodzi, Zora, Łódź.

JĘDRZEJCZAK M., 2005, Muzeum Tradycji Niepodległościowych $w$ Łodzi $i$ jego wykorzystanie przez ruch turystyczny, master thesis written in the Institute of Urban Geography and Tourism Studies, University of Łódź, Łódź.

KAŹMIERCZAK E., 2004, Funkcja kulturalno-turystyczna Muzeum Sztuki w Łodzi, master thesis written in the Institute of Urban Geography and Tourism, University of Łódź, Łódź.

KOTER M., LISZEWSKI S., SULIBORSKI A., 2000, Łódź i region Polski Środkowej. Podręcznik wiedzy o regionie dla liceów, Łódzkie Towarzystwo Naukowe, Łódź.

KOWALCZYK A., 2001, Geografia turyzmu, PWN, Warszawa.

KRAKOWIAK B., 2008, Muzea jako miejski walor turystyczny, [in:] I. Jażdżewska (ed.), Funkcja turystyczna miast, XXI „Konwersatorium Wiedzy o Mieście", Wyd. Uniwersytetu Łódzkiego, Łódź, pp. 205-214.

KRAKOWIAK B., 2013, Miejsce muzeów w turystyce kulturowej w Polsce, Turyzm/Tourism, 23/2, pp. 23-33.

KRAKOWIAK B., SKRYDALEWICZ 2013, Noc muzeów jako wydarzenia kulturalne w wybranych miastach Polski, [in:] R. Wiluś, J. Wojciechowska (eds.), Nowe-stare formy turystyki w przestrzeni, ser. „Warsztaty z Geografii Turyzmu”, vol. 3, pp. 115-134, Wyd. Uniwersytetu Łódzkiego, Łódź.

LISZEWSKI S., 2009, Miejska przestrzeń eksploracji turystycznej, Turyzm, 19/1, pp. 51-73.

MOKRAS-GRABOWSKA J., 2011, Charakterystyka ruchu turystycznego w Muzeum Sztuki ms2 w Łodzi, Turystyka $i$ Hotelarstwo, 1, pp. 139-158.

LAURENTOWICZ-GRANAS M., MANŻETT-KUBiAK J., 1997, Pałace "Ziemi obiecanej", Towarzystwo Opieki nad Zabytkami, Oddział w Łodzi, Zora, Łódź.
NOWAKOWSKA S., 2012, Centralne Muzeum Wtókiennictwa jako element produktu turystycznego Łodzi, master thesis written in the Institute of Urban Geography and Tourism Studies, University of Łódź, Łódź.

Polityka rozwoju kultury 2020+ dla miasta Łodzi, 2013, załącznik do uchwały nr LIX/1252/13 Rady Miejskiej z 27 marca 2013 r.

Rocznik statystyczny województwa tódzkiego 2009, 2011, 2013, 2014, Urząd Statystyczny, Łódź.

Rocznik statystyczny województw, 2009, 2011, 2013, 2014, GUS, Warszawa.

Statystyka Łodzi, 2010, 2014, Urząd Statystyczny, Łódź.

WAWRZYNIAK J., 2008, Muzeum Fabryki jako nowa atrakcja turystyczna na terenie Łodzi, master thesis written in the Institute of Urban Geography and Tourism Studies, University of Łódź, Łódź.

WLAŹLAK A., 2011, Monografia Muzeum Farmacji w Łodzi, license thesis written in the Institute of Urban Geography and Tourism, University of Łódź, Łódź.

WOJALSKI M., 1998, Kieszonkowa kronika dziejów Łodzi, Widzewska Oficyna Wydawnicza „Zora”, Łódź.

WRZESIŃSKA K., 2011, Muzeum Książki Artystycznej w Łodzi i jego specyfika, license thesis written in the Institute of Urban Geography and Tourism Studies, University of Łódź, Łódź. www.msl.org.pl.

www.ncl.uml.lodz.pl. www.regiobooks.pl. www.TripAdvisor.com. www.waszaturystyka.pl.
Artticle received: 9 September 2015 